\title{
Penerapan Media Pembelajaran Mobuya pada Indahnya Keragaman Budaya Bangsaku di Sekolah Dasar
}

\author{
Tri Syamsijulianto \\ Sekolah Tinggi Keguruan dan Ilmu Pendidikan Melawi, Indonesia \\ Email: Syamsijulianto17@gmail.com
}

\begin{tabular}{l}
\hline Tersedia Online di \\
\hline http://www.jurnal.unublitar.ac.id/i \\
ndex.php/briliant \\
\hline Sejarah Artikel \\
\hline Diterima pada 11 Maret 2020 \\
Disetujui pada 18 April 2020 \\
Dipublikasikan pada 30 Mei 2020 \\
Hal. 209- 219
\end{tabular}

Kata Kunci:

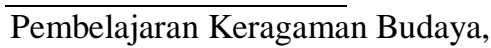
Media Pembelajaran Mobuya,

Hasil Belajar

\section{DOI:}

http://dx.doi.org/10.28926/briliant. v3i4.449

hipotesis nol (Ho) data terdistribusi dengan normal.

\begin{abstract}
Abstrak: Pembelajaran mengenai indahnya keragaman budaya negeriku disekolah dasar masih belum menggunakan media pembelajaran sebagai sarana untuk mengenalkan keragaman budaya yang ada dinegeriku, Guru juga dominan menggunakan buku teks sebagai sumber utama proses pembelajaran disekolah dasar sehingga berdampak kepada hasil belajaran dan aktifitas peserta didik dikelas. Tujuan penerapan media pembelajaran ini yaitu menghasilkan melihat apakah media pembelajaran Mobuya efektif dibelajarkan pada subtema indahnya keragaman budaya negeriku. Metode yang digunakan dalam penelitian ini adalah model penelitian eksperimen. Media yang digunakan dalam penelitian ini berupa media pembelajaran Mobuya, materi budaya yang ada di Kalimantan Barat, Nilai hasil transfomasi dari nilai posttest memberikan nilai sebesar 0.152 dengan probabilitas 0.192 terlihat bahwa pada hasil post test jauh diatas $\alpha=0.05$. Jadi dapat disimpulkan bahwa distribusi tersebut normal, dilihat dari
\end{abstract}

\section{PENDAHULUAN}

Subtema indahnya keragaman budaya negeriku merupakan salah satu bagian dari pembahasan tema pada kurikulum 2013. Kurikulum 2013 dibelajarkan untuk mendorong tercapainya standar yang diinginkan (Kemendikbud, 2017). Subtema pada kurikulum 2013 diajarkan untuk memberikan pengetahuan tentang indahnya keragaman budaya yang ada negeriku. Keragaman budaya itu belum sepenuhnya dipahami peserta didik (Belha $\mathrm{H}$, et al., 2015). Sehingga tercermin dalam kehidupan sehari-hari pada lingkungan peserta didik. Lingkungan peserta didik tercipta dari kebudayan serta pola pikir yang dimiliki oleh peserta didik untuk merubah tingkah laku serta pengetahuan sebagai hasil pembekalan pendidikan (Haqiqi \& Suprayitno, 2017). Jadi dapat disimpulkan bahwa dalam kehidupan sehari-hari keragaman budaya itu harus selalu diajarkan kepada peserta didik.

Berdasarkan wawancara yang dilakukan oleh peneliti terhadap guru kelas IV pada Sekolah Dasar 02 Beduai, yang dimana beliau menjelaskan bahwa guru jarang menggunakan media pembelajaran sebagai sarana untuk mengenalkan keragaman budaya yang ada dinegeriku, hal ini disebabkan karena biaya yang digunakan untuk membuat media pembelajaran cukup banyak, karena berbatasan dengan anggaran yang harus dikeluarkan itu maka guru jarang sekali menggunakan media pembelajaran. Guru juga dominan menggunakan buku teks sebagai sumber utama 
proses pembelajaran disekolah dasar sehingga berdampak kepada hasil belajaran dan aktifitas peserta didik dikelas.

Kurangnya minat belajar peserta didik menjadi permasalahan utama yang terjadi pada proses pembelajaran di sekolah Latief (2017). Lebih lanjut Azyura (2013) minimnya penggunaan media pada proses pembelajaran, dan guru hanya memanfaatkan buku guru dan buku siswa sebagai sumber belajarnya. Fakta lain yang terjadi pada sekolah dasar bahwa pemahaman guru dalam penerapan proses pembelajaran tidak memadai, guru tidak mampu menerapkan praktek pembelajaran dengan baik, sehingga berdampak kepada proses pembelajaran di sekolah dasar Okoro \& Okoro (2016). Jadi, seharusnya guru mampu menumbuhkan minat belajar peserta didik.

Solusi yang ditawarkan oleh peneliti dengan media pembelajaran menggunakan permainan monopoli berbasis budaya (Mobuya). Sejalan dengan hal tersebut Halloran, et al. (2017) salah satu metode yang dapat digunakan sebagai alat pengajaran, digunakan untuk mencoba melibatkan para siswa sepenuhnya dalam belajar berupa penggunaan permainan ataupun simulasi. Sehubungan dengan pernyataan mengenai media pembelajaran Mobuya D'Astous \& Gagnon (2007) mengclaim bahwa permainan papan seperti monopoli dapat dimainkan dan dimanfaatkan untuk media pembelajaran yang menyenangkan. Selain itu game dengan menggunakan papan monopoli juga dapat dikembangkan dalam bentuk media pembelajaran Mobuya. Lebih lanjut, Park (2017) menjelaskan permainan papan dapat dimainkan bersama-sama serta meningkatkan keterampilan sosial peserta didik.

Media pembelajaran Mobuya menjadi solusi untuk mengenalkan keragaman budaya. Pengenalan budaya kepada peserta didik dapat melalui belajar sambil bermain. Menurut Oktavianti \& Ratnasari (2017) penerapan monopoli budaya pada pembelajaran tematik untuk mengajarkan kepada peserta didik agar dapat belajar dari lingkungan individu dan kelompok. Mobuya dapat memberikan kontribusi yang positif dalam pengajaran tentang keberagaman budaya bangsaku serta memiliki dampak cukup luas untuk mengenalkan budaya daerah yang belum diketahui.

Penelitian yang dilakukan oleh Oktavianti \& Ratnasari (2017) permainan monopoli dapat menjadi media pembalajaran yang baik dalam pembelaran tematik maupun tematik terintegratif untuk mengenalkan budaya, selain itu dengan permainan monopoli ini anak-anak merasa tertantang untuk menyelesaikan permaian monopoli sehingga meningkatkan minat, keaktifan belajar serta meningkatkan pemahaman konsep pembalajaran tematik. Lebih lanjut, hasil temuan terbaru dari Maulida (2017) menunjukan media pembelajaran menggunakan permainan monopoli ini sangat cocok digunakan sebagai media pembelajaran di sekolah dasar.

Media pembelajaran Mobuya dibelajarkan dengan mengadopsi pembelajaran HOTS (Higher, Order, Thingking, and Skill), dengan proses pengenalan keragaman budaya yang ada di Kalimantan Barat, media pembelajaran Mobuya mampu memberikan peserta didik untuk memahami konsep-konsep keragaman budaya yang ada, serta dengan media pembelajaran Mobuya peserta didik juga akan memiliki sikap karakter yang akan tertanam dalam diri masingmasing peserta didik.

210 BRILIANT: Jurnal Riset dan Konseptual Volume 5 Nomor 2, Mei 2020 
Tujuan penerapan media pembelajaran ini yaitu menghasilkan melihat apakah media pembelajaran Mobuya efektif dibelajarkan pada subtema indahnya keragaman budaya negeriku. Harapan media pembelajaran Mobuya layak di terapkan pada proses pembelajaran indahnya keragaman budaya negeriku.

Media pembelajaran merupakan alat yang digunakan sebagai sebuah penghubung bagi guru dengan peserta didik dengan harapan dapat menghantarkan pengetahuan baru yang memberikan pembelajaran yang bermanka. Menurut Musfiqon (2016) media pembelajaran diartikan sebagai alat bantu yang sengaja digunakan sebagai perantara dalam menyampaikan materi pembelajaran sehingga menjadi lebih efektif, dan efisien. Pernyataan Musfiqon diatas diperkuat dengan pendapat Kosasih (2016) bahwa media pembelajaran sebuah alat yang digunakan untuk memperoleh pembelajaran yangbermakna sehingga peserta didik terlibat pada pengalaman pada proses pembelajaran, serta mampu meningkatkan kemampuan melihat, mendengara,merasakan, menghayati, mencium serta mencici pembelajaran itu, karena dengan menggunakan alat belajar yang menyenangkan akan meningktakan aktivitas mental, emosional, dan intelektualnya, sehingga media itu merupakan bahan atau pondasi pembelajaran yang sebenarnya.

Kriteria pemilihan media pembelajaran bersumber dari konsep bahwa media menjadi sumber instruksional secara keseluruhan dari penentuan media itu sebagai sumber belajar. Menurut Musfiqon (2016) menyebutkan ada beberapa kriteria yang harus diperhatikan dalam pemilihan media pembelajaran, sebagai berikut; a) tujuan pembelajaran sesuai dengan yang ingin dicapai dalam proses pembelajaran; b) isi pembelajaran mendukung fakta, konsep, prinsip dan generalisasi pelajaran; c) media berbentuk praktis, luwes serta bertahan lama; d) terampilnya guru dalam menggunakan media pembelajaran; e) sasaran pengelompokan media pembelajaran; f) mutu teknis.

Permainan monopoli merupakan salah satu media permainan yang dapat menimbulkan kegiatan belajar mengajar yang menarik, hidup, menyenangkan dan santai serta mempunyai kemampuan untuk melibatkan siswa dalam kegiatan belajar mengajar secara aktif dalam memecahkan masalah-masalah yang ada sehingga dapat meningkatkan hasil belajar siswa Fitriyawany (2013). Sejalan dengan hal tersebut menurut Siskawati \& Pargito, (2016: 38) permainan monopoli adalah salah satu permainan papan terkenal di dunia yang tujuan permainan ini adalah untuk menguasai semua petak di atas papan melalui pembelian, penyewaan dan pertukaran properti dalam sistem ekonomi yang disederhanakan.

Media pembelajaran mobuya adalah media permainan papan atau board game berbentuk strategi dan simulasi, yang kontennya berisi beragam budayabudaya lokal, dibentuk dalam sebuah permainan untuk mengenalkan keberagaman budaya daerah, sehingga lebih mempermudah memahami masing-masing budaya yang ada agar dapat mensyukuri keragaman itu untuk mengikat persatuan dan kesatuan.

\section{METODE}

Model penelitian dan pengembangan biasanya dikenal dengan research and development atau yang populer disebut dengan penelitian $R \& D$ utamanya untuk menciptakan sebuah produk baru yang merupakan jenis penelitian untukmeningkatkan kinerja dalam pembelajaran itu bisa berupa media pembelajaran, dan lain sebagainya, dan selain dari pada itu juga digunakan untuk melakukan 
pemercahan masalah praktis dalam penelitian, yang utamanya itu adalah penelitian pendidikan dan pembelajaran. Sejalan dengan itu Sugiyono (2015) metode penelitian dan pengembangan atau research and development adalah metode penelitian yang digunakan untuk menghasilkan produk tertentu dan menguji keefektifan produk tersebut.

Evaluasi di lakukan dalam rangka untuk mengetahui lebih dalam berkaitan dengan media yang diterapkan. Menurut Tegeh, dkk., (2014:43) dalam melakukan evaluasi ini hal yang hendak diperhatikan peneliti adalah penggunaan evaluasi atau assesment yang digunakan meliputi evaluasi sumatif atau evaluasi formatif. Evaluasi sumatif dilakukan pada akhir program untuk melihat pengaruh dari media pembelajaran yang di lakukan, sedang evaluasi formatif berupa pengumpulan data pada setiap tahap yang digunakan untuk penyempurnaan. Sejalan dengan itu menurut Aldoobie (2015) tahap ini dilakukan untuk memastikan bahwa media yang kembangkan telah mencapai tujuan dari desain instruksional yang di rencanakan. Selain itu Cheung (2016) tahap evaluasi digunakan untuk mengetahui efektifitas dari penerapan media pembelajaran yang berikan, selain itu pada tahap ini untuk mendapatkan umpan balik yang sumatif, umpan balik formatif dapat dan harus dikumpulkan seluruh program instruksi untuk mengaktifkan perbaikan inkremental.

Data yang digunakan dalam penelitian ini yaitu deskriptif kuantitatif. Data kuantitatif digunakan untuk penerapan media pembelajaran Mobuya, peneliti mengumpulkan data dari validasi ahli media pembelajaran, ahli materi, dan ahli lapangan atau praktisi, selain itu data kuantitatif juga untuk mengetahui respon dari peserta didik terhadap produk media pembelajaran Mobuya, data yang digunakan berupa kuesioner untuk dijawab oleh peserta didik, data kuantitatif diperoleh dari hasil penilaian terhadap media pembelajaran Mobuya yang ada pada kuisioner yang sebarakan, data-data tersebut berupa angka secara keseluruhan dari kuesioner yang diberikan kepada peserta didik serta dari kuesioner yang diberikan kepada validator.

Adapun instrument yang digunakan berupa observasi, kuesioner, lembar validasi. Observasi dilakukan untuk melihat proses pembelajaran terutama media pembelajaran Mobuya di sekolah, kuesioner digunakan untuk mendapatkan informasi dari guru dan untuk melihat seberapa paham peserta didik produk yang diberikan kuesioner angket berupa soal untuk guru sebanyak 20 soal dengann model ceklist yang menggunakan skala Guttman dengan interval "ya" dan "tidak" serta untuk peserta didik 15 soal. Model yang digunakan dalam kuesioner ini adalah model checklist adapun untuk penskorannya menggunakan skala Guttman dengan interval"ya" dan "tidak". Untuk ahli media pembelajaran menggunakan skala likert interval 4, 3, 2, 1. Sedangn untuk evaluasi terhadap kelayakan media pembelajaran digunakan soal essay sebanyak 10 soal.

Teknik analisis yang digunakan dalam penelitian ini adalah dengan menggunakan teknik analisis deskriptif kuantitatif. Teknik ini digunakan untuk menilai kelayakan penerapan dari media pembelajaran Mobuya serta tingkat kualitas produk Mobuya yang dikembangkan. Analisis ini juga dilakukan untuk mendeskripsikan persentase keberhasilan dari uji coba hasil penelitian berupa aspek kognitif, afektif dan psikomotorik. Selain itu dalam penerapan media pembelajaran Mobuya, analisis data respon yang diberikan oleh peneliti kepada peserta didik berupa kuesioner yang telah disebarkan yang disikan oleh peserta didik, ahli media

212 BRILIANT: Jurnal Riset dan Konseptual Volume 5 Nomor 2, Mei 2020 
pembelajaran, ahli materi, dan ahli penerapan pembelajaran atau praktisi lapangan. Kemudian dilakukan.

Untuk melihat keefektifan media pembelajaran Mobuya. Pada hari pertama peneliti melakukan pretest untuk mengetahui pengetahuan awal peserta didik. Pada hari kedua peneliti memberikan posttest atau evaluasi pada akhir kegiatan pembelajaran. Tujuan dari pemberian posttest untuk mengukur seberapa efektifkah media pembelajaran Mobuya untuk diterapkan pada kegiatan pembelajaran di kelas IV sekolah dasar. Skor hasil yang digunakan untuk analisis keefektifan ini dari hasil belajar yang dilakukan pada akhir pembelajaran. Posttest dilakukan untuk memperoleh gambaran kemampuan yang telah dicapai siswa setelah penyampaian materi pelajaran dan untuk mengetahui perbedaan hasil belajar.

Setelah data hasil evaluasi pembelajaran dari pretest dan posttest atau evaluasi dari kelas sesudah menggunakan media pembelajaran Mobuya diperoleh dari akhir pembelajaran untuk mengetahui perbedaan hasil belajar sebelum perlakuan dan sesudah perlakuan dengan media pembelajaran Mobuya, kemudian dilanjutkan uji $\mathrm{t}$ dengan menggunakan paired sample t test atau sample yang berhubungan, dengan analisis dengan bantuan program komputer program SPSS 22. Tujuan melakukan uji t dengan paired sample $t$ test adalah untuk melihat ada peningkatan atau tidaknya peningkatan sesudah dan sebelum di berikan perlakuan,

Uji beda atau menggunakan uji $\mathrm{t}$ untuk menghitung rata-rata antara hasil pretest dan posttest ini dapat digunakan untuk mencari kesimpulan dari penelitian. Uji efektifitas produk atau uji beda produk dilakukan dengan membandingkan dua nilai rata-rata dengan standar error dari perbedaan rata-rata sample dari posttest dan pretest.

\section{HASIL}

Tabel 1. Hasil Analisis dan interpretasi terhadap Validasi Media pembelajaran kedua

\begin{tabular}{|c|c|c|c|c|c|c|c|}
\hline \multirow{2}{*}{$\begin{array}{l}\text { Banyak Item } \\
\text { Pertanyaan }\end{array}$} & \multicolumn{4}{|c|}{$\begin{array}{c}\text { Frequensi dengan skala } \\
\text { likert (skala 4) }\end{array}$} & \multirow{2}{*}{$\begin{array}{l}\text { Skor } \\
\text { Perolehan }\end{array}$} & \multirow{2}{*}{$\begin{array}{l}\text { Persentase } \\
\text { Perolehan }\end{array}$} & \multirow{2}{*}{$\begin{array}{l}\text { Konversi } \\
\text { Interpretasi }\end{array}$} \\
\hline & 1 & 2 & 3 & 4 & & & \\
\hline \multirow[t]{2}{*}{31} & & 2 & 28 & 1 & 92 & 74,19 & $\begin{array}{l}\text { Cukup layak } \\
\text { dapat } \\
\text { diperguanakan }\end{array}$ \\
\hline & & & & & & & Revisi Kecil \\
\hline \multicolumn{5}{|c|}{$V-a h=\frac{(2 \times 2)+(28 \times 3)+}{(31 \times 4)}$} & $\frac{X 1)}{X 100}$ & \multicolumn{2}{|c|}{$\frac{92}{124} \times 100=74,19$} \\
\hline
\end{tabular}

Validasi media pembelajaran dilakukan ahli media pembelajaran validasi tersebut bertujuan untuk mengetahui tingkat kevalidan dari media pembelajaran Mobuya. Jumlah total skor yang diperoleh dari kevalidan media pembelajaran Mobuya tersebut yaitu sebesar 85 dengan skor maksimal 120, Skor yang diperoleh kemudian dimasukkan dalam $V-a h=\frac{T s e}{(T s h)} X 100, \quad$ maka diperoleh $V-a h=$ $\frac{(5 X 2)+(25 X 4)}{(30 \times 4)} X 100=\frac{85}{120} X 100$, sehingga persentase hasil yang diperoleh dari ahli media pembelajaran adalah $70,833 \%$. hasil validasi media pembelajaran kriteria validitas produk Cukup Layak.

Tabel 2. Hasil Uji Beda Terhadap Pretest dan Posttest Paired Sample Statistics, Corelation, dan paired sample test 
Paired Samples Statistics

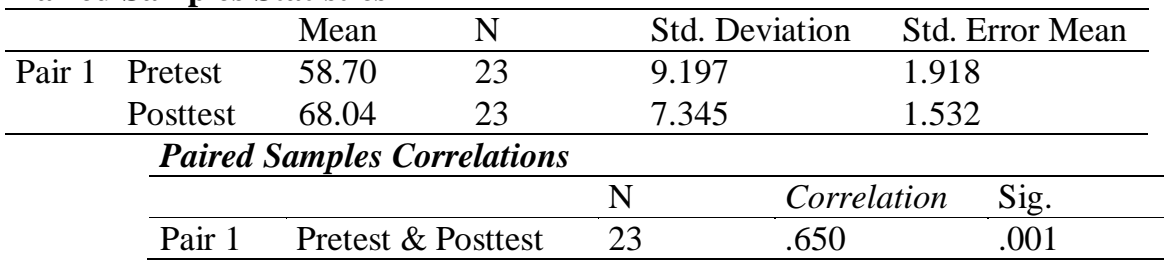

Paired Samples Test

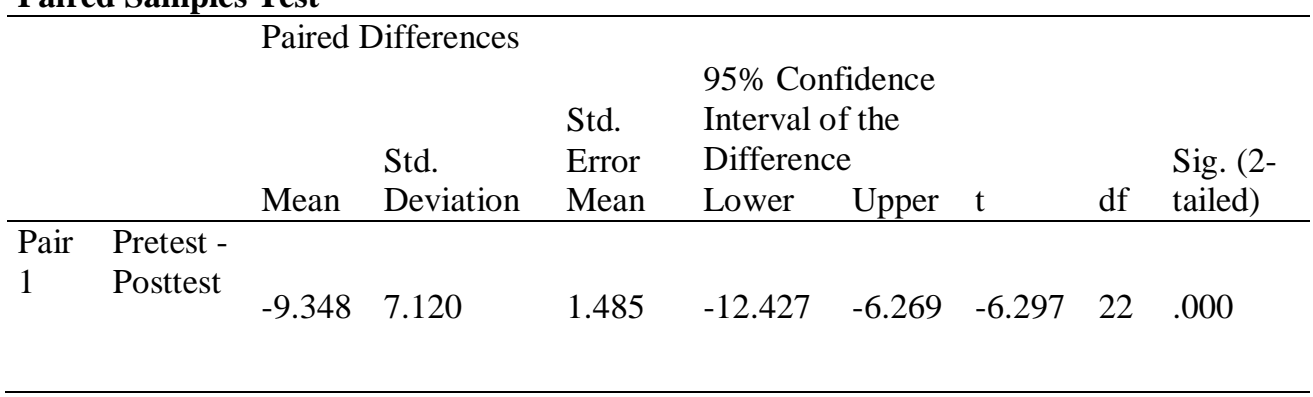

Berdasarkan table statistic dan sample test terhadap penerapan media pembelajaran yang dilakukan analisis uji beda yang memiliki sampel yang berhubungan hasil yang diperoleh dari 23 orang peserta didik yang sebelum dikenakan penerapan dengan mean dari pretest dan posttest. Perbedaan antara pretest dan posttest telihat signifikan secara statistic sebesar 58,70 untuk pretest dan sedangkan untuk posttest sebesar 68, 04 hal ini dapat di amati dari nilai t statistic -6.297 yang menujukan adanya korelasi antara pretest dan posttest. Korelasi antara media pembelajaran Mobuya sebesar .650 dengan taraf signifikansi .001 , jika dilihat dari nilai siginifkasi terdapat hubungan antara penerapan media pembelajaran Mobuya dengan hasil belajar yang telah diterapkan. Diketahu dari hasil analisis terhadap pretest dan posttest bahwa nilai signifikansi 2 tailed (sig. 2tailed) sebesar $0,000<0,05$, maka dapat disimpulkan bahwa terdapat perbedaan variasi nyata antara hasil belajar dengan menggunakan media pembelajaran Mobuya pada pembelajaran tematik pada data pretest dan posttest.

\begin{tabular}{|c|c|c|}
\hline \multicolumn{3}{|c|}{ One-Sample Kolmogorov-Smirnov Test } \\
\hline $\mathrm{N}$ & & 23 \\
\hline \multirow{2}{*}{ Normal Parameters ${ }^{\mathrm{a}, \mathrm{b}}$} & Mean & .0000000 \\
\hline & Std. Deviation & 4.56888476 \\
\hline \multirow[t]{3}{*}{ Most Extreme Differences } & Absolute & .151 \\
\hline & Positive & .089 \\
\hline & Negative & -.151 \\
\hline Test Statistic & & .151 \\
\hline Asymp. Sig. (2-tailed) & & .192 \\
\hline \multicolumn{3}{|l|}{ a. Test distribution is Normal. } \\
\hline \multicolumn{3}{|l|}{ b. Calculated from data. } \\
\hline \multicolumn{3}{|c|}{ c. Lilliefors Significance Correction. } \\
\hline
\end{tabular}

Berdasarkan uji normalitas pada penerapan media pembelajaran Mobuya, untuk jumlah peserta yang dikenakan penerapan sebanyak 23 orang dari jumlah 24 siswa yang seharusnya. Nilai hasil transfomasi dari nilai posttest memberikan nilai sebesar 0.152 dengan probabilitas 0.192 terlihat bahwa pada hasil post test 
jauh diatas $\alpha=0.05$. Jadi dapat disimpulkan bahwa distribusi tersebut normal, dilihat dari hipotesis nol (Ho) data terdistribusi dengan normal.

\section{PEMBAHASAN}

Peserta didik terlihat lebih senang dalam proses pembelajaran dengan menggunakan media pembelajaran Mobuya. Belajar sambil bermain sesuai dengan karakteristik peserta didik (Hedman, 2011). Berdasarkan penelitian Latief et al. (2017) belajar dengan monopoli memberikan pembelajaran menyenangkan sehingga tidak monoton. Melalui media pembelajaran Mobuya sesuai dengan karakteristik peserta didik, sehingga akan memudahkan peserta didik untuk memahami pembelajaran. Peserta didik terlihat senang belajar dengan media pembelajaran Mobuya.

Guru smemberikan penjelasan kepada peserta didik mengenai petunjuk penggunaan media pembelajaran Mobuya. Berdasarkan penjelasan yang diberikan oeh guru, peserta didik terlihat bingung. Kemudian guru mendekati peserta didik untuk menjelaskan. Namun selain itu, ada salah satu peserta didik yang berusaha untuk mendengarkan penjelasan yang disampaikan oleh guru. Guru menjelaskan bahwa dengan kartu-kartu pada media pembelajaran Mobuya dapat menciptakan pemahaman peserta didik dalam memahami konsep pembelajaran tematik menganai keragaman budaya (Ratnasari, 2017). Peserta didik sudah memahami cara menggunakan kartu Mobuya.

Guru memberikan kesempatan kepada peserta didik untuk membaca materi tentang keragaman budaya, bertujuan agar dalam pembelajaranpeserta didik dapat lebih mudah untuk mempelajari tentang budaya. Hal ini sejalan Susanto (2014) bahwa belajar tidak hanya sekedar memberikan pengetahuan tetapi lebih pada pemecahan masalah serta berusaha menggunakan ide-ide dalam pembelajaran..

Proses pelaksanaan pembelajaran Mobuya telah sesuai dengan tujuan pembelajaran dengan media pembelajaran Mobuya. Pendapat berbeda Rusdi (2017) tujuan dari media pembelajaran Mobuya itu bertujuan untuk mengenalkan budaya dan tatanan budaya masyrakat bisa lebih baik lagi. Melalui pembelajaran yang baik dapat memberikan pembelajaran yang menyenenangkan.

Penerapan media pembelajaran Mobuya sesuai dengan tujuan bahwa peserta didik diberikan kesempatan untuk memahami budaya, dan ternyata media pembelajaran juga efektif untuk gunakan pada media pembelajaran. Hal ini dapat dilihat dari taraf signifikansi media pembelajaran Mobuya terlihat Asymp. Sig. (2tailed) .192. ini menunjukan media pembelajaran Mobuya terdapat signifikasi di atas .005 data media pembelajaran Mobuya terdistribursi normal dan adanya signifasi proses media pembelajaran Mobuya.

Terlihat dari signifikasi pada proses penerapan media pembelajaran tersebut bahwa harapan dari media pembelajaran dapat dipenuhi. Harapan tersebut dapat dilihat memahami arti keragaman budaya, menjaga keberagaman budaya yang ada di Indonesia, menghargai keragaman budaya yang ada di Indonesia, mengenai keberagaman, memaknai pentingnya persatuan dan kesatuan dalam keragaman. Selanjutnya berdasarkan temuan Afifurrahman (2015) pengembangan media pembelajaran digunakan untuk medianpembelajaran dapat dikembangkan untuk mengenalkan keragaman budaya yang ada. Media pembelajara memiliki tujuan dapat memberikan pemahan kepada peserta didik mengenai kergaman budaya yang ada didaerahnya. 
Guru sedang bertanya mengenai keragaman yang ada di daerah setempat. Terlihat salah seorang peserta didik mencoba menjawab pertanyaan yang diberikan oleh guru. Peserta didik menjawab bahwa mereka sudah memahami keragaman budaya yang ada didaerah. Hal ini sejalan dengan hasil temuan dari Oktavianti \& Ratnasari (2018) akan memberikan kemudahan kepada peserta didik untuk memahami kearifan lokal serta menimbulkan kebanggaan tersendiri dengan kearifan lokal yang ada di daerahnya. Guru juga coba bertanya terhadap seorang peserta, apakah mereka senang dengan media Mobuya. Peserta didik menjawab bahwa mereka senang belajar dengan media pembelajaran Mobuya. Lebih lanjut temuan Minarti, et al. (2012) menumbuhkan aktifitas pembelajaran yang mampu mengenal pembelajaran pada proses pembelajaran dikelas. ini dapat dilihat dari gambar 5.4 berikut.

Pembelajaran dengan media pembelajaran Mobuya topik utama untuk mengenalkan keberagaman budaya yang ada di Kalimantan Barat tepatnya di Kabupaten Sanggau. Media pembelajaran Mobuya dapat mengenalkan keragaman budaya di daerah Kabupaten Sanggau. Keragaman bisa diajarkan kepada peserta didik melalui media pembelajaran belajar dan bermain dapat menjadi cara belajar untuk pembelajaran di sekolah dasar sehingga tercipta anak Indonesia yang akan benar-benar memahami keberagaman budayanya, melalui budaya dapat meningkatkan cinta terhadap kesatuan dan persatuan bangsanya.

Pada proses pembelajaranyang telah dilaksanakan tentu akan mendapatkan kelebihan dan kekurangn dalam penggunaan dan penerapan media pembelajaran yang telah dibuat. Menurut Sadiman, et al. (2014) kelebihan dari media papan berupa gambar yang disajiakn dapat dibongkar pasang sehingga dapat dipakai berkali-kali, penyajian simple dan mudah sehingga memberikan pemahaman peserta didik. Sedangkan temuan dari penelitian pengembangan media pembelajaran Mobuya kelebihan yang diperoleh bahwa media pembelajaran Mobuya digunakan untuk mengenal keragaman budaya yang ada di Kalimantan Barat atau kabupaten Sanggau, kartu yang digunakan mengarah pada pertanyaan HOTS, dan efektif untuk digunakan pada pembelajaran tema yang lainnya. Selanjutnya temuan. Kelebihan hasil temuan dari Ratnasari (2017) proses pembuatan mudah dan sederhana, penyimpanan mudah, warna yang menarik, dapat digunakan pada pembelajaran tematik terintegratif, mengembangkan multiple intelligence dan kearifan lokal. Jadi adapun kelebihan media pembelajaran Mobuya denga penelitian sebelumnya terdapat pada kartu yang menggunakan pertanyaan pada arah HOTS serta keragaman budaya yang rancangan itu berbeda.

Namun selain ada kelebihan pada media pembelajaran Mobuya juga masih banyak sekalian kekurangan yang masih dapat untuk digali sehingga media ini dapat di upraged kearah yang lebih baik lagi kekurangan media pembelajaran ini berupa media pembelajaran ini membuthkan waktu yang cukup lama dalam melaksanakan proses pembelajaran. Pemahaman awal konsep peserta didik mengenai materi tentang indah keragaman budaya negeriku yang dipelajarinya. Pada saat mensimulasikan siswa cenderung akan menyederrhanakan konteks sosialnya dan akan berdampak kepada pemahaman peserta didik dalam memperoleh kesan yang salah. Untuk lebih efektif dan efisien harus melibatkan semua peserta didik. Karena terlalu asyik bermain membuat peserta didik terlena dalam permainannya dan mebuat peserta tidak terfokus pada pembelajaran. Harus mempersiapkan konsep dengan baik sehingga memperoleh pembelajaran yang

216 BRILIANT: Jurnal Riset dan Konseptual Volume 5 Nomor 2, Mei 2020 
baik. Harus memahami konsep desain dan memahami karakteristik peserta didik dan terakhir berupa kartu media pembelajaran yang sulit untuk diambil dan digunakan pada pembelajaran.

Media pembelajaran Mobuya yang dilaksanakan pada proses pembelajaran masih menemukan banyak permasalahan yang dirasakan masih perlu dilakukan pengkajian kembali. Hal ini bertujuan agar media pembelajaran Mobuya dapat digunakan sebagai alternative yang sangat layak pada kegiatan pembelajaran. Permasalahan yang didapatkan pada saat proses pembelajaran berupa ada beberapa siswa masih sulit untuk menguasai pembelajaran, kartu pada media pembelajaran terlalu berat untuk usia sekolah dasar hal ini didasarkan kartu yang digunakan pertanyaan mengarah pada soal HOTS sedang peserta didik lebih ingin memahami keragaman budaya yang ada, selanjutnya tempat penyimpan kartu yang masih belum sempurna, warna dan gambar yang perlu disempurnakan, buku panduan dan materi yang perlu disepurnakan, dan penguasaan serta pemahaman guru juga perlu ditingkatkan sehingga pembelajaran dengan media pembelajaran Mobuya dapat lebih baik.

Secara keseluruhan dan pengembangan media pembelajaran berdasarkan teori dan pembahasan yang telah dilakukan. Terdapat kohorensi dengan hasil validasi media pembelajaran, materi dan teori serta hasil analisis dan penerapan bahwa media pembelajaran ini efektif, layak, praktis, serta media pembelajaran Mobuya ini pantas untuk diterapkan pada proses pembelajaran tematik disekolah dasar, namun tetap harus memperhatikan aturan serta masukan yang telah diberikan sehingga bisa lebih memperbaiki media ini kedepannya nanti.

\section{KESIMPULAN}

Penerapan media pembelajaran Mobuya sesuai dengan tujuan bahwa peserta didik diberikan kesempatan untuk memahami budaya, dan ternyata media pembelajaran juga efektif untuk gunakan pada media pembelajaran. Hal ini dapat dilihat dari taraf signifikansi media pembelajaran Mobuya terlihat Asymp. Sig. (2tailed) .192. ini menunjukan media pembelajaran Mobuya terdapat signifikasi di atas .005 data media pembelajaran Mobuya terdistribursi normal dan adanya signifasi proses media pembelajaran Mobuya

\section{SARAN}

Saran pemanfaatan dalam penggunaan media pembelajaran Mobuya ini adalah pengaturan posisi kelompok sebaiknya harus di atur sebelum pelaksanaan pembelajaran dengan media pembelajaran Mobuya, pengaturan waktu yang harus diperhitungkan sehingga proses pembelajaran dapat dilaksanakan dengan efisien, penggunaan media pembelajaran di dalam kelas harus lebih memahami karakteristik peserta didik yang ada pada tempat yang akan diterapkan. sebaiknya media pembelajaran Mobuya dilakukan dengan bermain peran, materi sebaiknya di paparkan sedikit pada proses pembelajaran untuk memberikan apersepsi pada peserta didik, pada proses penerapan pembelajaran Mobuya hendak memperhatikan kemapuan peserta didik

\section{DAFTAR RUJUKAN}

A, M. (2017). No Title. Program Studi Guru Sekolah Dasar Fakultas Keguruan Dan Ilmu Pendidikan Universitas Muhammadiyah Purwekerto. 
Afifurrahman, L. H. S. (2015). Pengembangan Permainan Monopoli Panakawan Dalam Pembelajaran Tematik Integratif Tema Pengalamanku Untuk Kelas I

Sekolah Dasar Negeri Temu Ii Kanor Bojonegoro, 1-7.

Ahmad Rusdi. (2017). PENGGUNAAN ICT DAN KONTEKS BUDAYA, (January 2013). https://doi.org/10.13140/RG.2.2.11220.40321

Aldoobie, N. (2015). ADDIE Model Analysis phase. American International Journal of Contemporary Research, 5(6), 68-72. https://doi.org/10.13140/2.1.4687.6169

Azyura, E. N. M. (2018). Pengaruh Media Scrapbook Terhadap Hasil Belajar IPS Tema 7 Indahnya Keragaman di Negeriku Kelas IV. JPGSD, 06(08), 14171426.

Belha H, A., Undari, S. R., Yahya, W. I., Sa, N., \& Widowati, I. (2015). Pobundo (Pop-Up Budaya Indonesia) Sebagai Media Pembelajaran Berbasis Kebudayaan Untuk Siswa Kelas Iv Sekolah Dasar. PELITA, X(1), 65-76.

Cheung, L. (2016). Using the ADDIE Model of Instructional Design to Teach Chest Radiograph Interpretation. Journal of Biomedical Education, 2016, 1-6. https://doi.org/10.1155/2016/9502572

D'Astous, A., \& Gagnon, K. (2007). An inquiry into the factors that impact on consumer appreciation of a board game. Journal of Consumer Marketing, 24(2), 80-89. https://doi.org/10.1108/07363760710737085

Fitriyawany. (2013). Penggunaan Media Permainan. Jurnal Ilmiah DIDAKTIKA, XIII(2), 223-239.

Halloran, R. O., Deale, C., Halloran, R. O., Ph, D., Deale, C., \& Ph, D. (2017). Designing a Game Based on Monopoly as a Learning Tool for Lodging Development Designing a Game Based on Monopoly as a Learning Tool for Lodging Development, 3758(October). https://doi.org/10.1080/10963758.2010.10696983

Haqiqi, N. \& S. (2017). Penggunaan Media Monopoli Untuk Meningkatkan Hasil Belajar Siswa Pada Materi Keragaman Ekonomi Di Indonesia Dalam Tema Indahnya Keragaman Di Negeriku Di Kelas Iv Sdn Babatan I/456 Surabaya. JPGSD, 05(03).

Hedman, E. (2011). The Frustration of Learning Monopoly: The Emotional Tension of Entering a New Game Encounter. The Ethnographic Praxis in Industry Conference, Boulder, (2001), 18-21.

Kemendikbud. (2017). Indahnya Keragaman di Negeriku.

Kosasih, E. (2016). No Title. Bandung: Penerbit Yrama Widya.

Latief, M., Kimia, J., \& Makassar, U. N. (2017). Pengembangan Permainan Ular Jarra Sebagai Media, 20, 101-107.

maya siskawati, pargito, P. (2016). Pengembangan Media Pembelajaran Monopoli Untuk Meningkatkan Minat Belajar Geografi Siswa. Studi Sosial, 4(1), 72-80.

Minarti, I. B., Susilowati, S. M. E., \& Indriyanti, D. R. (2012). Perangkat Pembelajaran Ipa Terpadu Bervisi Sets Berbasis Edutainment Pada Tema Pencernaan. Journal of Innovative Science Education, 1(2), 7. Retrieved from http://journal.unnes.ac.id/sju/index.php/jise

Musfiqon, H. (2016). No Pengembangan Media Dan Sumber PembelajaranTitle. Jakarta: Prsestasi Pustaka.

Okoro, C.O. (Ph.D) and Okoro, C. U. (2016). TEACHERS' UNDERSTANDING AND USE OF THEMATIC APPROACH IN TEACHING AND LEARNING 
OF SOCIAL STUDIES IN RIVERS STATE Okoro, C.O. (Ph.D) and Okoro, C.U. University of Port Harcourt, 4(3), 64-69.

Oktavianti, Ika \& Ratnasari, Y. (2017). Permainan Monopoli Engklek Jelajah

Budaya Pati Untuk Pembelajaran Tematik. Pendidikan Bahasa Dan Sastra Indonesia (PBSI) FKIP Universitas Muria Kudus, 63-71.

Oktavianti, I., \& Artikel, I. (2018). Media Berbasis Kearifan Lokal, 8(2).

Park, J. W. (2017). Hybrid Monopoly: A Multimedia Board Game that Supports Bidirectional Communication between a Mobile Device and a Physical Game Set. Multimedia Tools and Applications, 76(16), 17385-17401. https://doi.org/10.1007/s11042-017-4589-x

Sadiman, A. S., Rahardjo, R., Haryono, A., \& H. (2014). Teori Belajar \& Pembelajaran di Sekolah Dasar. Jakarta: Rajawali Press.

Sugiyono. (2016). Metode Penelitian Pendidikan: Pendekatan Kauntitatif, Kualitatif, Dan R\&D. Bandung: Alfabeta.

Susanto, A. (2014). Pengembangan Pembelajaran IPS di Sekolah Dasar. Jakarta: Kencana. 